\title{
Use of the histopathology in the differential diagnosis of drowning in fresh and salty water: an experimental model establishment in rats ${ }^{1}$
}

\author{
Uso da histopatologia no diagnóstico diferencial de afogamento \\ em água doce e água salgada: estabelecimento de modelo experimental em ratos
}

\author{
Rafael Fagionato Locali², Marcos de Almeida ${ }^{3}$, Itamar Souza de Oliveira-Júnior ${ }^{4}$ \\ 1. Research developed in Laboratory of Inflammatory Mediators, Division of Infection Diseases, and Laboratory of Pathology, Division \\ of Pathologic Anatomic General, Systemic, Forense and Bioethical of the Department of Pathology, Federal University of Sao Paulo \\ (UNIFESP). Brazil. \\ 2. Graduate student of Medicine of UNIFESP. Brazil. \\ 3. Full Professor of the Division of Pathologic Anatomic General, Systemic, Forense and Bioethical of the Department of Pathology of \\ UNIFESP. Brazil. \\ 4. PhD and Researcher of the Division of Infection Diseases and Head of the Laboratory of Inflammatory Mediators of UNIFESP. Brazil.
}

\begin{abstract}
Purpose: To develop a method of differential diagnosis to drowning, due to analysis of the alveolar macrophages quantitative, in rats submitted to induced drowning in fresh water and salty water. Methods: Were used 15 male adult rats Wistar EPM1, weight 360g ( $S D=21,3)$, randomized in three groups: G1- Control; G2- Fresh water; G3- Salty water, each one with n=5. The animals have been anesthetized and tracheostomized to insert a cannula inside the trachea, for drowning induction. The lungs have been removed, weighed, prepared for histology and colored by immunohistochemistry. The macrophages have been counted in both lungs (right and left) of each animal. The statistical test used was ANOVA (SPSS.10) with $\mathrm{p}<0,05$. Results: The amount of macrophages was $\mathrm{G} 3>\mathrm{G} 2>\mathrm{G} 1$ with $\mathrm{p}=0,0001$ in each comparison. The weight of lungs of G3 and G2 was higher than G1, with p>0,0001, however G3 and G2 do not possess difference statistics in the weight of lungs. Conclusion: The developed diagnostic method was efficient in rats. The results, if expanded, will be able to assist the Forensic Pathology for technique of low cost and high trustworthiness.
\end{abstract}

Key words: Drowning. Macrophages, Alveolar. Diagnosis, Differential. Rats.

\section{RESUMO}

Objetivo: Desenvolver um método de diagnóstico diferencial de afogamento, pela análise quantitativa dos macrófagos alveolares, em ratos submetidos à afogamento induzido em água doce e água salgada. Métodos: Foram utilizados 15 ratos adultos, machos Wistar EPM-1, pesando 360g (DP=21,3), randomizados em três grupos: G1 - controle; G2 - Água doce; G3 - Água salgada, cada um com n=5. Os animais foram anestesiados e traqueostomizados para inserção de uma cânula endotraqueal, para indução do afogamento. Os pulmões foram removidos, pesados, preparados para histologia e corados por imunohistoquímica. Os macrófagos foram contados em ambos os pulmões (direito e esquerdo) de cada animal. O teste estatístico utilizado foi o ANOVA (SPSS.10) com p<0,05. Resultados: A quantidade de macrófagos foi G3>G2>G1 com p=0,0001, entretanto, G3 e G2 não possuem diferença estatística no peso dos pulmões. Conclusão: O método diagnóstico desenvolvido foi eficiente em ratos. Os resultados, se expandidos, serão capazes de auxiliar a Patologia Forense por uma técnica de baixo custo e alta confiabilidade.

Descritores: Afogamento. Macrófagos Alveolares. Diagnóstico Diferencial. Ratos.

\section{Introduction}

The diagnosis of drowning as the cause of death can be very difficult and problematic in individual cases, especially when typical morphological signs of drowning are not present and/or where the body was drowning. Every year drowning claims between 6 and 8000 people in the United States, and most of these victims are children or young. ${ }^{1,2}$ Drowning is defined as a flood of the breathing treatment with liquid fluid, generating an accentuated compromising of the lung function and interrupting the gaseous changes. Soon after the anóxia begins, culminated in asphyxia and death. ${ }^{3,4}$ Rivers, lakes and oceans are representative places of larger drowning incidence. ${ }^{5}$ Significant portion of the current deaths of drowning is for homicide, tends, therefore, special relevance for the Forensic Pathology. ${ }^{6-8}$ However, the presented methodologies generate nonsense among the authors, mainly when the differentiation is discussed among drowning happened in fresh water and/or salted water., ${ }^{3,9,10}$ Therefore, this article proposes the development of a safe and low cost technique to solve this conflict. 


\section{Methods}

\section{Animal experiments}

All methods were approved by the Institutional Research Committee at Federal University of Sao Paulo, in accordance with National Institute of Health (NIH) Guideline Reagarding Animal Experimentation.

\section{Animal preparation and surgical technique}

Male Wistar rats ( $n=15$, bodyweight 340-380 g) were fasted overnight with free access to food and water ad libitum. Rats were anaesthetized with sodium thiopental (40 mg/kg bw, Thionembutal, ABBOTT, SP, Brazil) intraperitoneally (ip). Animals were placed in the supine position and 1\% lidocaine was injected subcutaneously of the region of the trachea. Tracheostomy was performed, and a 14-gauge cannula was advanced to a position approximately $1 \mathrm{~cm}$ above the carina (Figure 1 ).

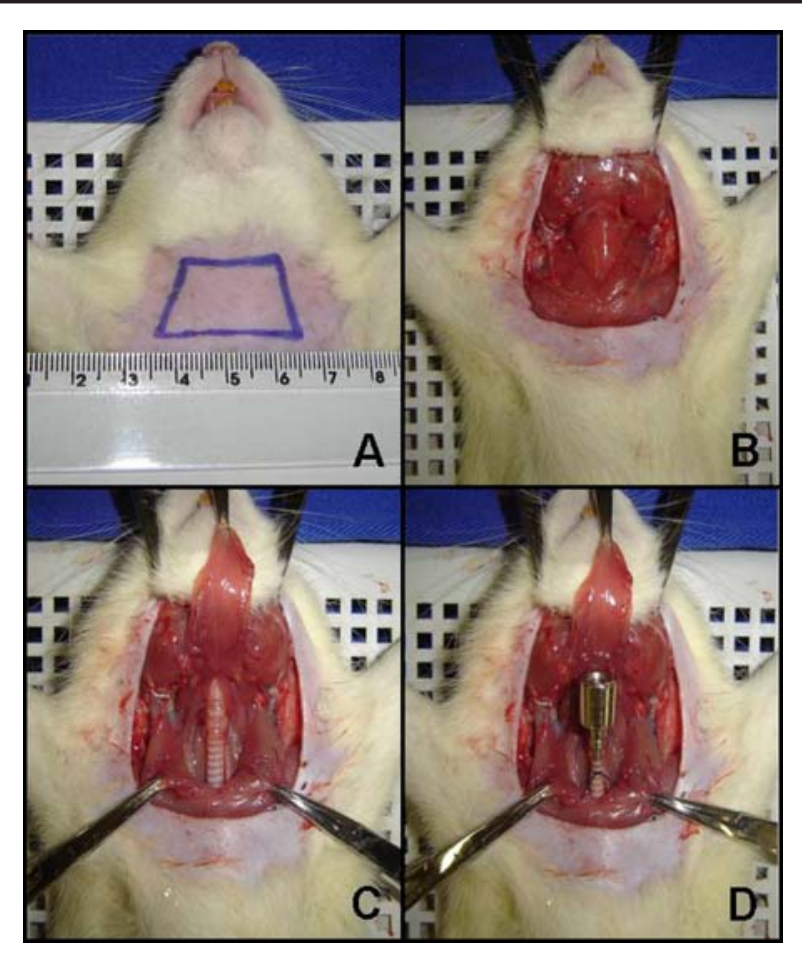

FIGURE 1 - Surgical technique: A - Landmark of the operative field; B - Presentation of the cervical muscles; C - Exposition of the trachea; D - Insertion of the 14-gauge cannula

\section{Experimental protocol}

The water were colected in two points: 1) Fresh Water: the fresh water used was collected of the Guarapiranga dam, city of São Paulo-SP, face to face to the number 151, of the Valentim Ramos Delano Street, and to 35 meters, inside of the dam, starting from your margin. The collection was accomplished at 11 hours (a.m). 2) Salty Water: the salted water was collected at the Boqueirão beach, city of SantosSP, face to face to the number 10 of the Praia Vicente de Carvalho Avenue, located among the channels three and four. For collection were counted 35 meters, inside of the water, starting from the margin, at 11 hours (a.m).

The rats were randomized in 3 groups $(n=5$ each group): Group 1 - control; Group 2 - the rats were drowning with approximately $30 \mathrm{~mL} / \mathrm{kg}$ bw of the fresh water, infusion taxe by $1 \mathrm{~mL} / \mathrm{min}$, and Group 3 - the rats were drowning with approximately $30 \mathrm{~mL} / \mathrm{kg}$ bw of the salty water, infusion taxe by $1 \mathrm{~mL} / \mathrm{min}$. The survival period, time between the beginning of fluid instillation and cardiac arrest, was shorter than 3 minutes. Immediately after death the lungs were removed and fixed in 10\% formolaldehyde (Figure 2). Specimens were prepared for histology, colorated with monoclonal antibody CD-68 (mouse anti-human macrophage, clone KP1, code $n^{\circ} \mathrm{M} 0814$, Dako).

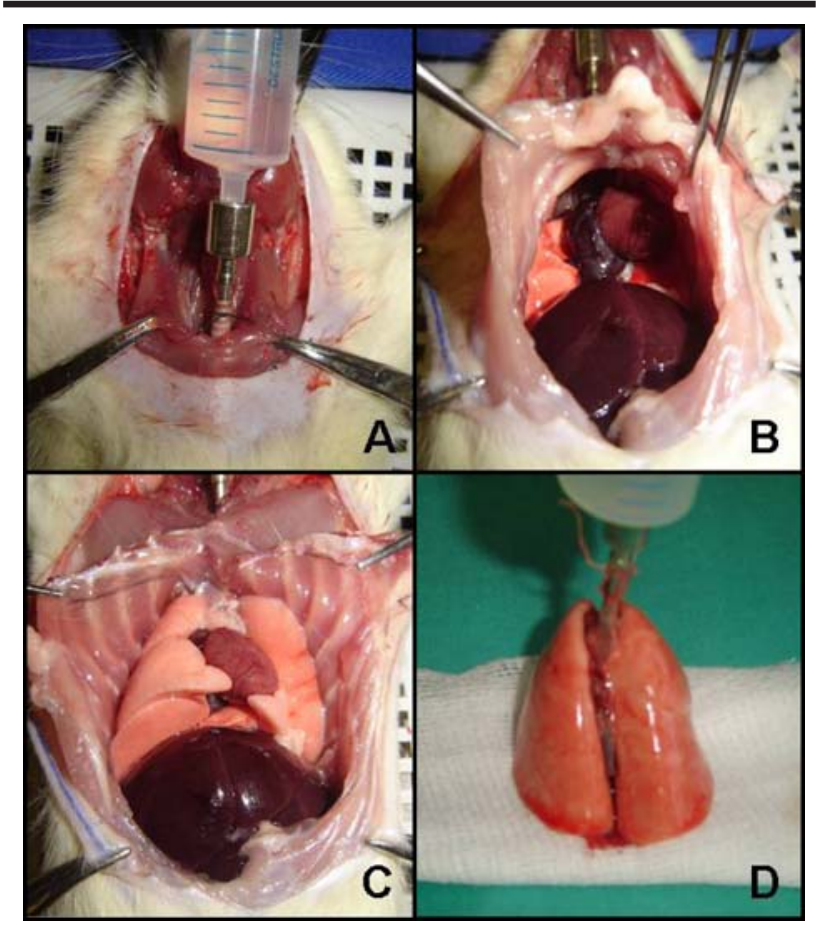

FIGURE 2 - A - Rats being drowning; B - Incision subxiphoid; C - Sternum opening; D - Remove of the lungs

\section{Statistical analysis}

The statistical analysis accomplished using the SPSS statistical software (SPSS 10, SPSS Science, IL, USA). Oneway rank analysis of variance followed by Tukey-Kramer adjustament. Data are reported as means \pm S.D. A $P$ values < 0.05 was considered to be statistically significant.

\section{Results}

The statistical analysis demonstrated that the macrophage numbers were increased in the lungs of the animals of the group G2 and G3 when compared with the group $\mathrm{G} 1$ ( $p=0,0001)$. The macrophage numbers in the lungs 
of the group G3 was increased when compared with the group $\mathrm{G} 2$ ( $\mathrm{p}=0,0001)$ (Figure 3 ). The weight of the lungs of the animals of the group G3 and G2 was increased when compared with control group $(\mathrm{G} 1 ; \mathrm{p}=0,0001)$. However, there was not difference weight statistics among the lungs of the groups G2 and G3 (Figure 4).

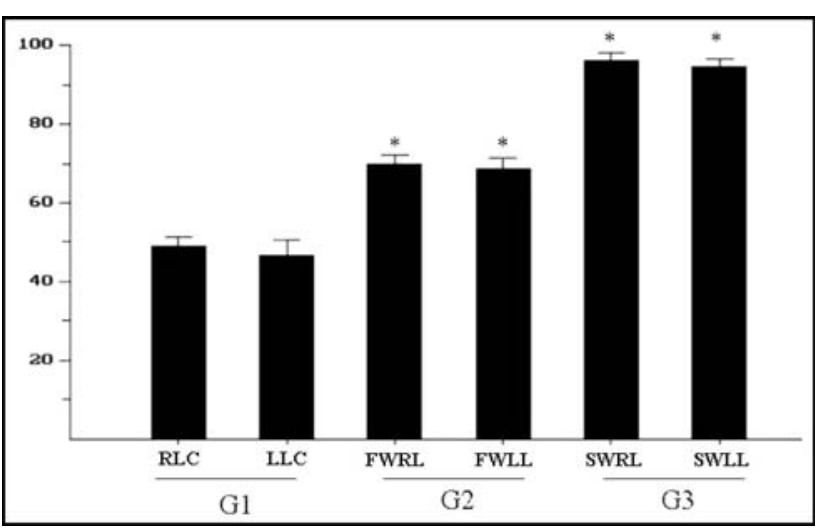

FIGURE 3 - Demonstrates the macrophage numbers found in the histologic analysis. When analyzed among equal we found statistical difference in: RLC vs. FWRL, p=0.001; RLC vs. SWRL, $\mathrm{p}=0.001$; FWRL vs. SWRL, $\mathrm{p}=0.001$; LLC vs. FWLL, $\mathrm{p}=0.001$; LLC vs. SWLL, $\mathrm{p}=0.001$; FWLL vs. SWLL, $\mathrm{p}=0.001$. Abbreviations: $\mathrm{RLC}=$ right lung control; LLC= left lung control; FWRL= fresh water in right lung; FWLL= fresh water in left lung; SWRL= salty water in right lung; and SWLL= salty water in left lung.



FIGURE 4 - Demonstrates the weight of the lungs, right and left, after the procedure. When we analyzed the weight of the lungs among equal we found statistical difference in: RLC vs. FWRL, $\mathrm{p}=0.001$; RLC vs. SWRL, $\mathrm{p}=0.001$; FWRL vs. SWRL, $\mathrm{p}=0.001$; LLC vs. FWLL, $\mathrm{p}=0.001$; LLC vs. SWLL, $\mathrm{p}=0.001$; FWLL vs. SWLL, $\mathrm{p}=0.001$. Abbreviations: RLC= right lung control; LLC= left lung control; FWRL= fresh water in right lung; FWLL= fresh water in left lung; SWRL= salty water in right lung; and SWLL= salty water in left lung.

\section{Discussion}

The drowning is prostrated as a dilemma for the forensic medicine. It is unquestionable that considerable portion of the drownings occur due to homicides, in spite of this there are cases in which this elapses as consequence of accidents. A range of situations exists for a dead individual's emergence to be questioned in a river, lake or ocean. In homicides, the killer can, for instance, suffocate the victim and then throw the body in a lake, or, still, an individual drowned in a river can have the body found in the ocean. In that aspect, it is of considerable importance that the medical expertise stop diagnosis means to determine, with high sensibility and specificity, the form the crime had been executed.

Several studies describe significant differences in the death mechanism provoked by the drowning in fresh and salty water. ${ }^{11-13}$ Classic studies of Swann, with experimental models, demonstrated that different changes hemodynamics and biochemistries happen in drownings in fresh water and salted. ${ }^{14,15}$ When the drowning happens in fresh water, there is an accelerated diffusion of hypotonic water of the lungs for the circulatory system, resulting in hipervolemia, hemodilution, hemolysis and decrease of the seric electrolytes serices, except for the potassium. The potassium concentration increased in the blood due to the hemolysis. In the drowning in salted water, the eletrolites presents in the water are diffused for the circulation due to the concentration gradient. For similar process flowed them blood they are diffused for the alveoli. At the same time, the alterations that happen are hypoproteinemia, hipovolemia, hemoconcentration and lung edema. ${ }^{8}$

The results show a significant increase in the macrophage numbers in the animals drowned in salted water, when compared with drowned in fresh water. Both drowned groups had a significant increase in the number of the alveolar macrophages when compared to the control group.

However, Betz et al, in his results verified a decrease in the number of present alveolar macraphages in the individuals' lungs when the individual was slain by drowning in fresh water, when compared to the controls. ${ }^{10}$ That discrepancy of results can be related to the considerable number of variables in the casuistry included in the study.

Another expressive discovery was the independence of the amount of macrophages in relation to location. The count of the alveolar macrophages, in the left and right lungs of each animal it was not significant ( $p>0.05)$. This indicates that it is possible to analyze the drowning in fragments of any lung, independently of the location of the histologic cut.

The authors suggest that a study is accomplished in humans, with expressive casuistry, to establish a parameter of the amount of alveolar macrophages in individuals that came to death, for drowning in fresh and/or salted water, besides a control with cause non drowning mortis. With that, he settles down a quantitative standardization of alveolar macrophages that can be used in the diagnosis diferencial by the Forensic Pathology. 


\section{Conclusion}

The method used for differential diagnosis by drowning in fresh and/or salted water was effective in rats. The results, if expanded, can corroborate with the confirmation of the place where the death really happened, for a technique of low cost and of considerable reliability for the Forensic Pathology.

\section{References}

1. Ritchie BC. The physiology of drowning. Med J Aust. 1972; 2:1187-9.

2. Nacional Safety Council. Accident facts, 1993. Itasca, Ill: Nacional Safety Council, 1993.

3. Pachar JV, Cameron JM. The diagnosis of drowning by quantitative and qualitative diatom analysis. Med Sci Law. 1993; 33(4):291-9.

4. Gauto A, Majeski JA, Alexander JW. Drowning and neardrowning: current concepts. South Med J. 1979; 72(6):690-2.

5. Olshaker JS. Near drowning. Emerg Med Clin North Am. 1992; 10:339-50.

6. Copeland AR. Homicidal drowning. Forensic Sci Int. 1996; 31:247-52.
7. Szpilman D. Near-drowning and drowning classification: a proposl to stratif mortality base don the analysis of 1,831 cases. Chest. 1997; 112(3): 660-5.

8. Tiperman J. The diagnosis of drowning: a review. Forensic Sci. 1972; 1:397-409.

9. Kobayashi M, Yamada Y, Zhang W, Itakura Y, Nagao M, Takatori T. Novel detection of plankton from lung tissue by enzymatic digestion method. Forensic Sci Int. 1993; 60:81-90.

10. Betz P, Nerlich A, Penning R, Eisenmenger W. Alveolar macrophages and the diagnosis of drowning. Forensic Sci Int. 1993; 62:217-24.

11. Modell JH. Drowning. N Engl J Med. 1993; 328:253-6

12. Levin Dl, Morriss FC, Toro LO, Brink LW, Turner GR. Drowning and near drowning. Pediatr Clin North Am. 1993; 40:321-36.

13. Giammona ST, Modell JH. Drowning by total immersion. Effects on pulmonary surfactant of distilled water, isotonic saline, and seawater. Am J Dis Child. 1967; 114:612-6.

14. Swann HG, Brucer M, Moore C. Fresh water and sea water drowning: a study of the terminal cardiac and biochemical events. Tex Rep Biol Med. 1947, 5:423-38.

15. Swann HG, Brucer M. The cardiorespiratory and biochemical events during rapid anoxic death. VI. Fresh water and sea water drowning. Tex Rep Biol Med. 1949; 7:604-18.

\section{Correspondence:}

Itamar Souza de Oliveira-Júnior

Rua Pedro de Toledo, 781/11

04039-062 São Paulo - SP Brazil

itamarjr-pneumo@pesquisa.epm.br
Conflict of interest: none Financial source: none

Received: January 05, 2006

Review: February 10, 2006

Accepted: March 14, 2006

\section{How to cite this article:}

Locali RF, Almeida M, Oliveira-Júnior IS. Use of the histopathology in the differential diagnosis of drowning in fresh and salty water: an experimental model establishment in rats. Acta Cir Bras. [serial on the Internet] 2006 July-Aug;21(4). Available from URL: http://www.scielo.br/acb 